Dikirim: 16 Desember 2016 Diterbitkan: 1 Maret 2017

\section{Faktor-faktor yang berhubungan dengan kejadian kanker serviks di rumah sakit Sardjito Yogyakarta}

\author{
Related factors for cervical cancer incidence in Dr. Sardjito \\ Hospital in Yogyakarta
}

Dwi Putri Sulistiya Ningsih ${ }^{1}$, Dibyo Pramono ${ }^{2}$, Detty Nurdiati ${ }^{3}$

\section{Abstract}

Purpose: This study aimed to determine the factors associated with the incidence of cervical cancer in Dr. Sardjito Hospital. Methods: A case control study was conducted from July to October 2016. A total of 105 cases and 105 controls were included in the study. Cases were patients suffering from cervical cancer based on doctor's diagnosis, and controls were patients who do not have cervical cancer. Sampling was done by consecutive sampling technique. Data were analyzed by chi-square and logistic regression tests. Results: Factors associated with incidence of cervical cancer in Sardjito hospital were the first age variable for sexual intercourse $\leq 20$ years with aOR of 2.41 (95\% Cl: 1.35-4,29; $p=0.003$ ) and use of oral contraceptive/pill with aOR of 3.40 (95\% Cl: 1.46-7.92; $p=0.004)$, while the number of pairs, parities, pads, circumcision and smoking were not associated with the incidence of cervical cancer. Conclusion: Women who have not been sexually active can vaccinate for HPV. Also, they need to use condoms when having sex. Women aged 30-49 years (sexually active) are expected to be able to follow the early detection program of cervical cancer with visual inspection method of acetic acid which can now be done in health centers and have a pap smear examination at least once a year.

Keywords: cervical cancer; case control

\footnotetext{
${ }^{1}$ Departemen Biostatistik, Epidemiologi dan Kesehatan Populasi, Fakultas Kedokteran, Universitas Gadjah Mada (Email: dwiputri238@gmail.com)

${ }^{2}$ Fakultas Kedokteran Gigi, Universitas Gadjah Mada

${ }^{3}$ Departemen Obstetri dan Ginekologi, Fakultas Kedokteran, Universitas Gadjah Mada
} 


\section{PENDAHULUAN}

Kanker serviks termasuk penyebab utama kematian wanita di dunia. Kanker serviks menduduki urutan tertinggi di negara berkembang dan berada di urutan ke 10 di negara maju atau urutan ke 5 secara global. Di Indonesia, kanker serviks berada di posisi pertama dari 10 kanker terbanyak. Indonesia merupakan negara dengan kanker serviks terbesar di dunia $(1,2)$.

Tahun 2012 diperkirakan 528.000 kasus baru kanker serviks. Sebagian besar beban global terjadi di daerah kurang berkembang dan berkontribusi 12\% dari semua kanker pada wanita. Daerah yang berisiko tinggi, berdasarkan age standardized rate (ASRs) lebih dari 30 per 100.000 populasi Afrika Timur (42,7), Melanesia $(33,3)$, Afrika Selatan (31,5), dan Afrika Tengah (30,6). Jumlah terendah di Australia/Selandia Baru (5,5) dan di Asia Barat $(4,4)$. Kanker serviks paling umum terjadi pada wanita di Afrika Timur dan Tengah $(3,4)$.

Data riset kesehatan dasar menunjukkan prevalensi kanker serviks $(0,8 \%)$ dan kanker payudara $(0,5 \%)$ tertinggi di Indonesia pada tahun 2013. Sementara, provinsi Yogyakarta mempunyai prevalensi kanker serviks tertinggi (1,5\%) (5). Peningkatan kasus kanker serviks terjadi setiap tahun. Kanker serviks masuk 3 besar dari penyakit kanker di rumah sakit Sardjito. Kunjungan pasien di rawat jalan mencapai 2.965 dan di rawat inap sebanyak 647 kasus.

Kanker serviks dipengaruhi faktor sosiodemografi (usia, status sosial ekonomi) dan faktor aktivitas seksual (usia pertama kali berhubungan seksual, pasangan seksual berganti-ganti dan tidak disirkumsisi, paritas, kurang menjaga kebersihan genital), merokok, riwayat penyakit kelamin, riwayat keluarga penderita kanker serviks, trauma kronis serviks, penggunaan pembalut dan pantyliner, dietilstilbestrol (DES) dan penggunaan kontrasepsi oral $(1,6)$.

Wanita yang memiliki pasangan seksual lebih dari 1 dan paritas yang tinggi menjadi faktor risiko kanker sarviks (7). Sedangkan, merokok merupakan faktor risiko independen untuk kanker pada wanita yang terinfeksi HPV onkogenik (8). Usia dini pada saat berhubungan seksual dan kehamilan pertama kali meningkatkan risiko kanker serviks (9).

Jumlah perkawinan, riwayat abortus, pemakaian alat kontrasepsi hormonal, penggunaan pembalut, sabun $\mathrm{pH}>4$, status sosial ekonomi dan pasangan pria yang tidak disirkumsisi merupakan faktor risiko kejadian kanker serviks (10,11). Oleh sebab itu penelitian ini diperlukan. Penelitian ini bertujuan untuk mengetahui faktor yang berhubngan dengan kejadian kanker serviks.

\section{METODE}

Studi kasus kontrol selama bulan Juli-Oktober 2016. Sampel dihitung berdasarkan rumus dari Lemeshow. Jumlah kelompok kasus dan kontrol berbanding 1:1 tanpa matching. Sehingga diperoleh jumlah sampel sebanyak 105 kasus dan 105 kontrol. Kasus adalah pasien yang menderita kanker serviks berdasarkan diagnosis dokter. Kontrol adalah pasien yang tidak menderita kanker serviks. Pengambilan sampel secara teknik consecutive sampling. Pengumpulan data dilakukan dengan wawancara menggunakan kuesioner pada subjek penelitian dan diminta persetujuan secara tertulis untuk berpartisipasi dalam penelitian ini. Analisis data dilakukan secara deskriptif, dan bivariabel menggunakan uji chi-square dengan batas nilai kemaknaan $p<0,05$ dan interval kepercayaan 95\%. Analisis multivariabel menggunakan regresi logistik. Pemodelan awal dilakukan berdasarkan batas nilai kemaknaan $p<0,25$ dan secara bersama-sama dilakukan regresi logistik. Kemudian satu persatu variabel dengan nilai $p$ paling besar dikeluarkan, sehingga terbentuk model akhir. Penentuan model berdasarkan nilai AIC dan BIC dengan nilai terkecil.

\section{METODE}

Responden yang terdiagnosis sakit lebih besar pada kelompok usia 46-55 tahun. Adapun pada kelompok usia 26-35 tahun menunjukkan bahwa kanker serviks menyerang wanita lebih muda. Hasil uji homogenitas menunjukkan bahwa variansi kelompok usia responden saat terdiagnosis sakit adalah homogen.

Responden dengan pendidikan tinggi lebih banyak dibandingkan dengan pendidikan rendah. Penyebab perbedaan ini adalah pelaksanaan wajib belajar sekolah dasar yang dimulai pada tahun 1950 di wilayah Jawa Tengah, kemudian diresmikan program wajib belajar 6 tahun pada tahun 1984 dan dilanjutkan program wajib belajar 9 tahun pada tahun 1994. Hasil uji homogenitas menunjukkan bahwa variansi tingkat pendidikan pada kelompok kasus dan kontrol adalah homogen.

Mayoritas responden adalah ibu rumah tangga (IRT)/tidak bekerja dan masih mempunyai pasangan. Responden paling banyak dari penduduk Yogyakarta, sebagian merupakan pasien rujukan dari Jawa Tengah dan beberapa luar jawa seperti Sulawesi dan Papua. Hasil uji homogenitas menunjukkan ketiga variabel tidak homogen karena untuk pekerjaan beragam dari sektor formal dan non-formal, sedangkan untuk asal wilayah, berasal dari daerah yang berbeda. Sebagian 
besar kanker serviks telah berada pada stadium II B (30,48\%) dan paling sedikit stadium III dan IV B (0,95\%). Jenis histopatologi kanker serviks terbesar dari squamosa cell carcinoma dan adenocarsinoma. Sekitar 85\% termasuk jenis skuamosa (epidermoid), $10 \%$ jenis adenokarsinoma, 5\% jenis adenoskuamosa, clear cell, small cell, verucous.

Tabel 1. Ciri responden

\begin{tabular}{lcc}
\hline \multicolumn{1}{c}{ Variabel } & $\begin{array}{c}\text { Kasus } \\
(\mathbf{n = 1 0 5 )}\end{array}$ & Kontrol (n=105) \\
\hline $\begin{array}{l}\text { Kelompok usia responden } \\
\text { ketika didiagnosis sakit }\end{array}$ & & \\
26-35 tahun & 4 & 5 \\
36-45 tahun & 25 & 25 \\
46-55 tahun & 44 & 38 \\
56-65 tahun & 25 & 27 \\
66-75 tahun & 7 & 10 \\
Tingkat pendidikan & & \\
Pendidikan tinggi & 53 & 56 \\
Pendidikan rendah & 52 & 49 \\
Pekerjaan & & \\
Formal & 38 & 40 \\
Non formal & 10 & 20 \\
IRT/tidak bekerja & 57 & 45 \\
Asal wilayah & & \\
DIY & 50 & 61 \\
Jateng & 49 & 41 \\
Luar DIY dan Jateng & 6 & 3 \\
Status menikah & & \\
Menikah & 82 & 82 \\
Pisah/cerai hidup & 4 & 16 \\
Janda/pisah meninggal & 19 &
\end{tabular}

Tabel 2 menunjukkan variabel yang bermakna adalah usia pertama kali berhubungan seksual, jumlah pasangan seksual, paritas, penggunaan kontrasepsi jenis pil.

Tabel 2. Keterkaitan antar variabel penelitian

\begin{tabular}{lccc}
\hline \multicolumn{1}{c}{ Variabel } & $\begin{array}{c}\text { Kasus } \\
\text { (n= 105) }\end{array}$ & $\begin{array}{c}\text { Kontrol } \\
\text { (n= 105) }\end{array}$ & 95\% CI (OR) \\
\hline Usia pertama berhubungan seksual & \\
Usia $\leq 20$ tahun & 65 & 40 & $1,45-4,79^{*}(2,64)$ \\
Usia > 20 tahun & 40 & 65 & \\
Jumlah pasangan & & & \\
$>$ 1 pasangan & 18 & 7 & $1,08-8,56^{*}(2,89)$ \\
1 pasangan & 87 & 98 & \\
Paritas & & & \\
$\geq 4$ orang & 36 & 19 & $1,19-4,75^{*}(2,36)$ \\
< 4 orang & 69 & 86 & \\
Sirkumsisi & & & \\
Tidak & 12 & 9 & $0,25-1,98(0,72)$ \\
Ya & 93 & 96 & \\
Penggunaan pembalut & & \\
Ya & 56 & 62 & $0,44-1,41(0,79)$ \\
Tidak & 49 & 43 & \\
Penggunaan kontrasepsi & & \\
Oral/Pil & 28 & 13 & $1,60-9,84^{*}(3,94)$ \\
Suntik & 27 & 26 & $0,85-4,23(1,90)$ \\
Implan & 4 & 3 & $0,37-17,86(2,44)$ \\
IUD & 22 & 19 & $0,89-5,04(2,12)$ \\
Tidak pakai & 24 & 44 & $0,20-202,05(3,42)$ \\
Status merokok & & & \\
Perokok pasif & 95 & 96 & \\
Merokok & 3 & 1 & \\
Tidak merokok & 7 & 8 & \\
\hline
\end{tabular}

Tabel 3 menunjukkan bahwa model 3 merupakan model yang terbaik karena terdapat variabel usia pertama kali berhubungan seksual dan penggunaan kontrasepsi. Model 3 mendapatkan dukungan positif lebih baik di bandingkan model 2. Model regresi ini mempunyai nilai kalibrasi yang baik. Perhitungan LRoc menunjukkan hasil sebesar 0,6783, sehingga dapat diinterpretasikan model 3 memiliki nilai predictif yang baik karena area under curve (AUC) mendekati angka 1. Penderita kanker serviks yang melakukan hubungan seksual pertama kali pada usia $\leq 20$ tahun dan menggunakan kontrasepsi oral/pil 2,10 kali lebih berisiko untuk menderita kanker serviks.

Tabel 3. Perbandingan antar model analisis

\begin{tabular}{|c|c|c|c|}
\hline \multirow[b]{2}{*}{ Variabel } & Model 1 & Model 2 & Model 3*** \\
\hline & $\begin{array}{c}\text { aOR } \\
\text { CI (95\%) }\end{array}$ & $\begin{array}{c}\text { aOR } \\
\text { CI (95\%) }\end{array}$ & $\begin{array}{c}\text { aOR } \\
\text { CI (95\%) }\end{array}$ \\
\hline \multicolumn{4}{|c|}{ Usia pertama kali berhubungan seksual } \\
\hline$\leq 20$ tahun & 1,81 & 2,20 & 2,41 \\
\hline$>20$ tahun & $0,96-3,40$ & $1,22-3,95^{*}$ & $1,35-4,29 *$ \\
\hline \multicolumn{4}{|c|}{ Jumlah pasangan } \\
\hline$>1$ pasangan & 2,53 & 2,36 & \\
\hline 1 pasangan & $0,95-678$ & $0,89-6,25$ & \\
\hline \multicolumn{4}{|l|}{ Paritas } \\
\hline$\geq 4$ tahun & 1,84 & & \\
\hline$<4$ tahun & 0,89-3,79 & & \\
\hline \multicolumn{4}{|c|}{ Penggunaan kontrasepsi } \\
\hline Oral/pil & $\begin{array}{c}3,52 \\
(1,49-8,30)^{*}\end{array}$ & $\begin{array}{c}3,42 \\
(1,46-8,01)^{*}\end{array}$ & $\begin{array}{c}3,40 \\
(1,46-7,92)^{*}\end{array}$ \\
\hline Suntik & $\begin{array}{c}2,00 \\
(0,93-4,28)\end{array}$ & $\begin{array}{c}1,95 \\
(0,91-4,16)\end{array}$ & $\begin{array}{c}1,98 \\
(0,93-4,20)\end{array}$ \\
\hline Implan & $\begin{array}{c}2,30 \\
(0,44-11,90)\end{array}$ & $\begin{array}{c}2,47 \\
(0,49-12,43)\end{array}$ & $\begin{array}{c}2,23 \\
(0,44-11,24)\end{array}$ \\
\hline IUD & $\begin{array}{c}1,86 \\
(0,81-4,25)\end{array}$ & $\begin{array}{c}1,96 \\
(0,86-4,45)\end{array}$ & $\begin{array}{c}1,94 \\
(0,86-4,37)\end{array}$ \\
\hline Tidak pakai & 1 & 1 & \\
\hline BIC & 306,674 & 304,130 & 302,022 \\
\hline AIC & 279,897 & 280,701 & 281,940 \\
\hline
\end{tabular}

\section{BAHASAN}

Usia pertama kali berhubungan seksual bertepatan pada saat perkawinan, karena biasanya seseorang akan melakukan hubungan seksual jika sudah dalam ikatan perkawinan. Hubungan seksual merupakan awal risiko hamil. Oleh karena itu, usia pertama kali berhubungan seksual berkaitan dengan fertilitas. Data riset kesehatan dasar, diantara perempuan usia 10-54 tahun menikah pertama kali pada umur < 15 tahun (2,6\%) dan menikah pada umur 15-19 tahun (23,9\%). Menikah di usia dini termasuk problem kesehatan reproduksi. Semakin muda umur menikah, maka semakin panjang waktu untuk bereproduksi (5).

Analisis multivariabel menunjukkan wanita yang berhubungan seksual pertama kali pada usia $\leq 20$ tahun berisiko 2,41 kali lebih besar menderita kanker serviks dibandingkan dengan yang berhubungan seksual pertama pada usia > 20 tahun. Penemuan sejalan dengan penelitian Melva, terdapat perbedaan 
yang bermakna antara responden yang melakukan hubungan seksual pertama pada kelompok umur $<20$ tahun dengan ratio prevalens 2,330 dengan kejadian kanker serviks (14). Penelitian Setyarini menunjukkan bahwa responden yang menikah pada usia $\leq 20$ tahun berisiko terkena kanker serviks 5 kali lebih besar dibandingkan dengan responden yang menikah pada usia > 20 tahun (15). Penelitian sesuai dengan studi Umri, yang menunjukkan terdapat hubungan antara usia pertama kali berhubungan seks $<20$ tahun dengan kanker serviks, tetapi hubungan menjadi tidak bermakna setelah ada pengontrolan terhadap paritas dan tingkat pendidikan responden OR menjadi 2,1 (95\% CI 0,55-8,39) (16).

Semakin muda usia seorang wanita melakukan hubungan seks, kemungkinan terkena kanker serviks semakin besar. Hal ini didukung oleh penelitian Zarchi yang melakukan evaluasi faktor risiko kanker serviks pada wanita di rumah sakit Yazd-Iran dari tahun 2002-2009. Penelitian menunjukkan bahwa dari 100 orang pasien kanker serviks, $84 \%$ menikah pada usia di bawah 18 tahun dengan rata-rata usia pasien saat menikah adalah 15 tahun (17). Penelitian Louie menyatakan usia terlalu muda saat pertama kali berhubungan seks menjadi faktor risiko kanker serviks di 8 negara berkembang. Wanita yang melakukan hubungan seksual pertama kali pada usia 17-20 tahun berisiko 1,80 kali terkena kanker serviks, sedangkan wanita yang yang melakukan hubungan seks pertama kali pada usia $\leq 16$ tahun lebih berisiko 2,31 kali terkena kanker serviks (9).

Ketidakmatangan serviks secara biologis pada usia muda menjadi faktor risiko. Infeksi pertama kanker serviks terhadap HPV sering terjadi setelah hubungan seks yang pertama sehingga risiko kerentanan serviks yang belum matang terhadap infeksi HPV meningkat. Wanita yang mulai melakukan hubungan seksual pada usia $<20$ tahun lebih berisiko karena pada periode dewasa muda proses metaplasia sel skuamosa sangat meningkat sehingga berisiko terjadi transformasi atipik skuamosa meningkat yang kemudian menjadi neolpasia intraepitel cerviks (CIN) (18).

Fenomena menikah di usia muda disebabkan oleh budaya, tradisi, adat-istiadat, agama dan kepercayaan. Sebagian besar beranggapan peran perempuan adalah sebagai istri dan ibu, sehingga kemungkinan besar dinikahkan pada usia muda. Selain itu, akses untuk meningkatkan pendidikan dan keterampilan rendah. Namun, beberapa riset menunjukkan beberapa remaja memilih untuk menikah atas keinginan orang tua karena stigma perempuan dewasa yang tidak menikah, kekhawatiran terhadap kehamilan atau pengenalan seksual pranikah dan kemiskinan. Selain itu era globalisasi ini membuat para remaja juga terlibat pergaulan bebas, mengakibatkan perilaku seksual di luar nikah juga meningkat, sehingga permasalahan usia pertama kali berhubungan seksual yang terlalu dini menjadi masalah kompleks (19).

Data Survei SDKI 2012 penggunaan alat kontrasepsi secara nasional terbanyak adalah suntik (55,09\%), pil (23,49\%), IUD (6,74\%) dan implan (5,70\%). Kontrasepsi yang terbanyak di Yogyakarta adalah suntik $(45,47 \%)$ diikuti IUD (27,36\%), implan (7,65\%) dan pil (1,21\%). Di Jawa Tengah penggunaan alat kontrasepsi terbanyak adalah suntik (55,21\%), pil (16,45\%), implan $(9,45 \%)$ dan IUD (4,72\%) (20).

Penggunaan kontrasepsi oral atau pil berhubungan dengan kejadian kanker serviks. Kontrasepsi oral atau pil mengandung hormon dalam bentuk kombinasi progestin dengan estrogen atau progestin. Kontrasepsi mencegah kehamilan dengan menghentikan ovulasi dan menjaga kekentalan lendir serviks sehingga tidak dapat dilalui oleh sperma. Risiko kanker serviks meningkat, terutama jika pil telah dipakai lebih dari 5 tahun. Namun wanita yang menggunakan kontrasepsi pil memiliki risiko kanker ovarium atau kanker rahim yang lebih rendah (20).

Penemuan ini sejalan dengan penelitian Setyarini yang menyatakan terdapat hubungan yang bermakna antara penggunaan kontrasepsi oral dalam jangka waktu > 4 tahun dengan kanker leher rahim (15). Penelitian Vanakankovit menunjukkan terdapat hubungan antara penggunaan pil lebih dari 3 tahun dengan kejadian kanker serviks dengan. Hasil berbeda didapatkan dari penelitian Khasbiyah, tidak terdapat hubungan antara kontrasepsi oral atau pil dengan kejadian kanker serviks (22).

Kontrasepsi oral yang dipakai dalam jangka panjang yaitu lebih dari 5 tahun dapat meningkatkan risiko relatif seseorang menjadi 2 kali daripada orang normal. Proses tersebut diduga karena regulasi trasnkrip DNA virus dapat mengenali hormon dalam kontrasepsi pil, sehingga meningkatkan karsinogenesis virus. World health organization (WHO) melaporkan peningkatan risiko relatif pada pemakaian kontrasepsi oral/pil sebesar 1,19 kali dari normal yang meningkat seiring dengan lamanya pemakaian (18).

\section{SIMPULAN}

Fasilitas layanan kesehatan diharapkan untuk memberikan edukasi dan dukungan untuk membantu wanita melakukan deteksi dini kanker serviks. Pemberian konseling kepada remaja dan pasangan 
yang ingin menikah mengenai bahaya kanker serviks dan faktor penyebab seperti usia seksual dan melahirkan sebaiknya $\geq 20$ tahun, jumlah anak cukup 2 , tidak berganti-ganti pasangan, hygeine, penggunaan kontrasepsi $<4$ tahun.

\begin{abstract}
Abstrak
Tujuan: Penelitian ini bertujuan untuk mengetahui faktor yang berhubngan dengan kejadian kanker serviks di rumah sakit Sardjito. Metode: Studi case control dilakukan pada bulan Juli-Oktober 2016. Kasus adalah pasien yang menderita kanker serviks berdasarkan diagnosis dokter, dan kontrol adalah pasien yang tidak menderita kanker serviks. Pengambilan sampel dengan teknik consecutive. Data dianalisis dengan uji chi-square dan regresi logistik. Hasil: Sebanyak 105 kasus dan 105 kontrol dilibatkan dalam penelitian ini. Faktor yang berhubungan dengan kejadian kanker serviks di rumah sakit Sardjito Daerah Istimewa adalah usia pertama kali berhubungan seksual $\leq 20$ tahun dengan aOR sebesar 2,41 dan penggunaan kontrasepsi jenis oral/pil dengan aOR sebesar 3,40, sedangkan jumlah pasangan, paritas, pembalut, sirkumsisi, dan merokok tidak berhubungan dengan kanker serviks. Simpulan: Bagi wanita yang belum aktif seksual melakukan vaksinasi HPV. Penggunaan kondom ketika berhubungan seksual. Bagi wanita usia 30-49 tahun (aktif seksual) diharapkan untuk mengikuti program deteksi dini kanker serviks dengan metode inspeksi visual asam asetat (IVA) yang sekarang bisa dilakukan di puskesmas. Menjalankan pemeriksaan pap smear minimal $1 \mathrm{kali}$ dalam setahun.
\end{abstract}

Kata kunci: kanker serviks; case control

\section{PUSTAKA}

1. Kementerian Kesehatan. Panduan Program Nasional Gerakan Pencegahan dan Deteksi Dini Kanker. Kanker Leher Rahim dan Kanker Payudara. Jakarta: 2015.

2. Komite Nasional Penanggulangan Kanker. Panduan Nasional Penanganan Kanker. Jakarta: 2015.

3. Globocan. Cancer fact Street: cervical cancer incidence and mortality worldwide in 2012.

4. Ferlay J, Soerjomataram I, Dikshit R, Eser S, Mathers C, Rebelo M, Parkin DM, Forman D, Bray F. Cancer incidence and mortality worldwide: sources, methods and major patterns in GLOBOCAN 2012. International journal of cancer. 2015 Mar 1;136(5).
5. Kementerian Kesehatan. Pusat Data dan Informasi. Jakarta. 2015.

6. California Department of Health Care Services. Cancer of the cervix. 2013.

7. Ferrera A, Velema JP, Figueroa M, Bulnes R, Toro LA, Claros JM, de Barahona O, Melchers WJ. Co-factors related to the causal relationship between human papillomavirus and invasive cervical cancer in Honduras. International journal of epidemiology. 2000 Oct 1;29(5):817-25.

8. Kapeu AS, Luostarinen T, Jellum E, Dillner J, Hakama M, Koskela P, Lenner P, Löve A, Mahlamaki E, Thoresen S, Tryggvadóttir L. Is smoking an independent risk factor for invasive cervical cancer? A nested case-control study within Nordic biobanks. American journal of epidemiology. 2008 Dec 13;169(4):480-8.

9. Louie KS, De Sanjose S, Diaz M, Castellsague X, Herrero R, Meijer CJ, Shah K, Franceschi S, Munoz $\mathrm{N}$, Bosch FX. Early age at first sexual intercourse and early pregnancy are risk factors for cervical cancer in developing countries. British journal of cancer. 2009 Apr 7;100(7):1191-7.

10. Tira DS. Risiko Jumlah Perkawinan, Riwayat Abortus, Dan Pemakaian Alat Kontrasepsi Hormonal Terhadap Kejadian Kanker Serviks Di Rumah Sakit Pelamonia Makassar Tahun 2006-2007. InMKM 2008 Jun (Vol. 3, pp. 9-10).

11. Syatriani, S. (2011). Risk Factor of Cervical Cancer in Dr. Wahidin Sudirohusodo Government General Hospital Makasar, South Sulawesi. Jurnal Kesehatan Masyarakat Nasional. 2011 1(5).

12. Sankaranarayanan R. Cervical cancer in developing countries. Transactions of the Royal Society of Tropical Medicine and Hygiene. 2002 Nov 1;96(6):580-5.

13. Rasjidi I. Epidemiologi kanker serviks. Indonesian Journal of cancer. 2009 Oct 1;3(3).

14. Melva. Faktor-Faktor yang Mempengaruhi Kejadian Kanker Leher Rahim pada Penderita yang Datang Berobat di RSUP H. Adam Malik Medan Tahun 2008. Universitas Sumatera Utara.

15. Setyarini Eka. Faktor-Faktor Yang Berhubungan Dengan Kejadian Kanker Leher Rahim Di RSUD DR Moewardi Surakarta. Universitas Muhammadiyah Surakarta.

16. Umri S. Hubungan Usia Pertama Kali Melakukan Hubungan Seks dengan Kejadian Kanker Serviks di Rumah Sakit Haji Adam Malik Medan. Universitas Gadjah Mada.

17. Karimi MZ, Akhavan A, Gholami H, Dehghani A, Naghshi M, Mohseni F. Evaluation of cervical cancer risk-factors in women referred to Yazd-Iran hospitals from 2002 to 2009. Asian Pacific journal of cancer prevention: APJCP. 2010;11(2):537-8.

18. Pradipta B, Sungkar S. Penggunaan vaksin human papilloma virus dalam pencegahan kanker serviks. Jakarta: Fakultas Kedokteran Universitas Indonesia. 2007.

19. Badan Pusat Statistik. Analisis Data Perkawinan Usia Anak di Indonesia. Jakarta. 2016.

20. Badan Kependudukan dan Keluarga Berencana Nasional. 2015.

21. Moreno V, Bosch FX, Muñoz N, Meijer CJ, Shah KV, Walboomers JM, Herrero R, Franceschi S, International Agency for Research on Cancer (IARC) Multicentric Cervical Cancer Study Group. Effect of oral contraceptives on risk of cervical cancer in women with human papillomavirus 
infection: the IARC multicentric case-control study. The Lancet. 2002 Mar 30;359(9312):1085-92.

22. Khasbiyah. Beberapa Faktor Risiko Kanker Serviks Uteri: Studi pada Penderita Kanker Serviks Uteri di Rumah Sakit dr. Kariadi Semarang. Universitas Diponegoro. 